\title{
PELAKSANAAN MOODLE DI MASA PANDEMI COVID-19 PADA MATA PELAJARAN MATEMATIKA KELAS 11 IPA
}

\author{
Ega Altania, Sungkono \\ Jurusan Kurikulum dan Teknologi Pendidikan, Universitas Negeri Yogyakarta \\ egaaltaniaa@gmail.com
}

\begin{abstract}
Abstrak
Penelitian ini bertujuan untuk: (1) Menganalisis pelaksanaan e-learning Moodle. (2) Menganalisis manfaat dan dampak pelaksanaan e-learning Moodle. (3) Menganalisis faktor pendukung, faktor penghambat dan solusi dalam pelaksanaan e-learning Moodle. Penelitian ini merupakan penelitian deskriptif dengan pendekatan kualitatif. Hasil penelitian menunjukkan bahwa: (1) Perencanaan e-learning moodle meliputi perencanaan sarana dan prasarana, keadaan sumber daya manusia, RPP, Kurikulum Darurat pandemi covid 19, bahan ajar, dan materi pembelajaran. (2) Pelaksanaan e-learning Moodle meliputi kegiatan belajar mengajar yang dimulai dengan pengingat whatsapp grup, presensi, mengupload materi, mempelajari materi, mengumpulkan tugas, dan mendapatkan feedback berupa nilai dari guru. Model pembelajaran yang digunakan adalah problembased learning dengan metode penugasan, tanya jawab, dan diskusi. (3) Evaluasi yang dilakukan menggunakan evaluasi formatif dan evaluasi sumatif. (4). E-learning moodle memberikan manfaat pembelajaran menjadi lebih terorganisir serta dampaknya motivasi belajar stagnan dan keterbatasan komunikasi. (5) Faktor yang mendukung yaitu: kemandirian belajar, kesiapan belajar, kesehatan jasmani, bantuan paket data, materi pembelajaran, dukungan keluarga, dan sarana prasarana. Faktor yang menghambat yaitu: keterbatasan jaringan dan server down, solusinya dapat mengikuti susulan dan refresh web.
\end{abstract}

Kata kunci: E-Learning Moodle, Pembelajaran Matematika

\section{IMPLEMENTATION OF E-LEARNING MOODLE DURING THE COVID-19 PANDEMIC ON MATHEMATICS COURSE ELEVEN NATURAL SCIENCE SMA N 1 TEMANGGUNG}

\begin{abstract}
This study aims to: (1) Analyze the implementation of Moodle e-learning during the covid 19 pandemic in the 11th grade Mathematics subject of SMAN 1 Temanggung. (2) Analyze the benefits and impacts of implementing Moodle's e-learning.(3) Analyze the supporting factors, inhibiting factors and solutions in the implementation of Moodle e-learning. This research is a descriptive study with a qualitative approach. The results of the study indicate that: (1) Moodle e-learning planning includes planning of facilities and infrastructure, the state of human resources, lesson plans, the Covid-19 pandemic Emergency Curriculum, teaching materials, and learning materials. (2) The implementation of Moodle e-learning includes teaching and learning activities that start with WhatsApp group reminders, attendance, uploading materials, studying materials, collecting assignments, and getting feedback in the form of grades from the teacher. The learning model used is problem based learning with the method of assignment, question and answer, and discussion. Moodle e-learning provides the benefits of learning to be more organized. (3) The evaluation is carried out using formative evaluation and summative evaluation. (4). E-learning moodle provides the benefits of learning to be more organized and the impact of stagnant learning motivation and limited communication. (5) Supporting factors are: learning independence, learning readiness, physical health, data package assistance, learning materials, family support, and infrastructure. The inhibiting factors are: network limitations and server down, the solution can follow the follow-up and refresh the web.
\end{abstract}

Keywords: E-Learning Moodle, Mathematics Course 


\section{PENDAHULUAN}

Pembelajaran menurut Undang Undang Republik Indonesia Nomor 20 tahun 2003 tentang Sistem Pendidikan Nasional pasal 1 ayat 20 bahwa pembelajaran adalah suatu proses dalam melakukan hubungan timbal balik antara pendidik dengan peserta didik dan sumber belajar yang berlangsung dalam suatu lingkungan belajar atau lingkungan pembelajaran. Sedangkan menurut Hamalik (2002: 56) pembelajaran adalah suatu kombinasi yang tersusun meliputi unsur-unsur peserta didik dan juga pengajar, buku, papan tulis, kapur, dan alat belajar, fasilitas (ruang, kelas audio visual), dan proses yang saling memengaruhi mencapai tujuan pembelajaran. Dalam proses kegiatan belajar mengajar, perlu adanya komunikasi pembelajaran. Dimana komunikasi pembelajaran ini terjalin antara guru dan peserta didik dalam kegiatan belajar mengajar dengan tatap muka maupun kegiatan pembelajaran jarak jauh yang dapat menggunakan komunikasi verbal maupun non verbal dan secara individu maupun kelompok. Dengan adanya komunikasi antara guru dan peserta didik maka dapat membangun hubungan yang baik dan dapat membantu jalannya proses belajar mengajar. Komunikasi sangat berperan penting untuk menyalurkan pesan pembelajaran sehingga komunikasi berperan penting dalam mendukung proses belajar mengajar, tanpa adanya komunikasi pembelajaran tidak dapat berjalan dengan baik karena salah satu indikator keberhasilan proses pembelajaran atau pendidikan adalah komunikasi yang baik antara guru dengan peserta didik dan juga dengan menggunakan pola komunikasi akan mendorong kegiatan belajar mengajar menjadi lebih intensif dan juga kreatifitas berbicara akan menjadi terasah serta penemuan ide-ide baru dalam komunikasi antar guru dan peserta didik dapat membantu memahami informasi.

Dalam pembelajaran dibutuhkan pola komunikasi untuk memberikan informasi, Menurut pendapat Suranto (2010 : 116) yang menjelaskan bahwa pola komunikasi adalah suatu gejala umum yang menjelaskan cara interaksi yang terjadi dalam suatu kelompok tertentu. Pola komunikasi merupakan suatu cara yang dapat digunakan guru dan peserta didik dalam proses pembelajaran. Pola komunikasi yang digunakan tentu akan memudahkan peserta didik dalam menerima informasi, sehingga dengan adanya berbagai macam pola komunikasi akan dapat ditemukan pola yang cocok dan mudah digunakan dalam berkomunikasi. Pola komunikasi memiliki peranan yang penting dalam pembelajaran pada masa pandemi covid 19 yang berguna untuk menyampaikan informasi secara efektif dan efisien kepada peserta didik.

Pada akhir tahun 2019 ditemukan virus baru yaitu covid 19. Covid 19 adalah suatu virus yang menyerang saluran pernapasan manusia dan penyebarannya sangat cepat terjadi dari manusia ke manusia, virus corona adalah suatu virus baru yang sehingga belum diketahui secara pasti bagaimana sebenarnya virus ini muncul semuanya diupayakan untuk mendorong laju penyebaran penyakit covid 19 sehingga dengan ini virus covid 19 ditetapkan sebagai pandemi sehingga pembelajaran harus dilakukan secara online karena. Menurut Siahaan (2020: 73) virus corona merupakan suatu virus menular yang disebabkan oleh saluran pernapasan akut corona virus 2 (SARS-CoV-2). Penyakit ini pertama kali di id entifikasi pada Desember 2019 di Wuhan, China. Menurut Yuliana (2020: 188) coronavirus merupakan virus RNA strain tunggal positif, berkapsul dan tidak bersegmen. Gejala yang dapat ditimbulkan diantaranya demam, batuk, serta kesulian bernapas. Sehingga dengan adanya covid 19 ini mengharuskan sekolah mempersiapkan TIK. TIK adalah suatu teknologi yang digunakan untuk mengolah data, termasuk memproses, mendapatkan, menyusun, menyimpan, memanipulasi data dalam berbagai cara untuk dapat menghasilkan informasi yang berkualitas, informasi yang didapat tentunya harus akurat, tepat waktu, dapat digunakan dalam kepentingan pribadi, bisnis, maupun pemerintah. TIK adalah suatu teknologi yang dapat menghasilkan informasi dengan cepat dan akuat. TIK memberikan kemudahan bagi guru maupun peserta didik, peserta didik dapat belajar dimana saja, kapan saja tanpa harus bertemu langsung dengan guru. Peserta didik juga dapat mengatur sendiri kapan harus belajar sesuai dengan kemauannya masing-masing. Dengan adanya pandemi covid 19 maka sekolah dituntut untuk mempersiapkan adanya sarana dan prasarana yang digunakan untuk mendukung adanya TIK ini, sehingga dengan adanya TIK ini tentu sangat bermanfaat bagi kemandirian belajar peserta didik dan peserta didik secara aktif dalam memperoleh informasi yang diperlukan untuk mengerjakan tugas tanpa harus membeli buku teks. Konsep seperti ini disebut dengan E-Learning. 
E-Learning didefinisikan oleh Hartley (Darmawan, 2016: 62) e-learning merupakan suatu jenis media pembelajaran yang memungkinkan tersampaikannya informasi ke peserta didik dengan menggunakan media internet, intranet atau media jaringan computer. Sedangkan menurut Naidu (Prawiradilaga, 2016: 33) mendefinisikan e-learning sebagai penggunaan jaringan teknologi informasi dan komunikasi dalam proses belajar dan mengajar yan dilakukan oleh subjek yang ada dalam pembelajaran. Secara fundamental, e-learning adalah proses pendidikan yang memanfaatkan teknologi informasi dan komunikasi untuk menjembatani kegiatan belajar dan pembelajaran, baik secara syncronous ataupun asynchcronous. Sedangkan menurut Kusmana (Tigowati, 2017: 42) menyatakan bahwa:

"E-learning platform is an application that can connect to teachers and students in an online study space. E-learning is created to overcome the limitations between teachers and students."

Maksudnya disini adalah platform $e$ learning adalah aplikasi yang dapat terhubung dengan guru dan siswa dalam ruang belajar online. E-learning diciptakan untuk mengatasi jarak dan waktu antara guru dengan siswa, khususnya menyangkut ruang dan waktu. Oleh karena itu guru dan siswa hendaknya tidak berada dalam satu dimensi ruang dan waktu. Proses pendidikan dapat berjalan kapan saja dengan mengabaikan ruang dan waktu. Pembelajaran dapat terjadi dimana saja dan kapan saja, e-learning sangat cocok digunakan pada era sekarang serta memenuhi kebutuhan zaman yang sudah memasuki 5.0 ini, selain untuk mengatasi keterbatasan juga dapat digunakan sebagai sarana dan prasarana yang praktis untuk tetap dapat belajar dengan mudah karena e-learning dapat dikatakan sebagai inovasi dalam pembelajaran. Dari beberapa definisi atau pengertian di atas dapat disimpulkan bahwa e-learning adalah penggunaan secara sengaja jaringan teknologi informasi dan komunikasi sebagai penyampaian program pembelajaran, pelatihan, atau pendidikan dengan didukung oleh jasa elektronis seperti LAN, WAN, internet, telepon, audio, videotape, transmisi satelit atau komputer serta sebagai suatu platform pembelajaran yang dapat digunakan kapan saja dan dimana saja tanpa terikat ruang dan waktu. E-Learing memberikan kemudahan belajar kepada peserta didik untuk terus berkembang mengikuti perkembangan zaman dan melek teknologi begitu juga dengan guru. Pembelajaran dengan menggunkan e-learning membantu peserta didik untuk lebih kreatif dalam belajar dengan menggunakan berbagai macam sumber yang dapat diperoleh dengan mudah tanpa harus jauhjauh ke sekolah mencari suatu referensi. Dengan begitu e-learning memberikan kemudahan, efisien, dan efektivitas dalam perihal waktu dalam mencari suatu sumber referensi.

Ada berbagai macam e-learning yang dapat digunakan dalam pembelajaran diantaranya $e$ learning Moodle. E-learning dapat dikatakan sebagai inovasi yang dapat dimanfaatkan dalam proses pembelajaran untuk meningkatkan kemampuan belajar mandiri sehingga proses pembelajaran tidak hanya mengandalkan guru sebagai sumber belajar. Dengan adanya $e$ learning ini sangat bermanfaat bagi keberlangsungan pembelajaran di masa pandemi covid 19 untuk keefektifan pembelajaran. Elearning Moodle merupakan salah satu $e$ learning yang banyak digunakan.

E-learning Moodle memungkinkan siswa untuk masuk ke dalam ruang kelas digital untuk mengakses materi-materi pembelajaran secara online (Yuliastuti dkk., 2014: 3). Moodle adalah suatu media yang dapat di akses dengan mudah dengan komputer ataupun smartphone yang dihubungkan dengan jaringan internet. $E$ Learning Moodle merupakan software yang gratis untuk melakukan pembelajaran mandiri dengan tanpa terikat oleh waktu dan tempat. Moodle adalah suatu platform e-learning yang memberikan kemudahan organisasi pembelajaran agar suatu struktur pembelajaran online dapat berjalan dengan pengkondisian yang tepat dan tidak berantakan. Sifat dari $e$ learning Moodle yang dapat diunduh secara gratis dan dapat dimodifikasi oleh siapa saja, program ini menjadi solusi bagi pelaksanaan pembelajaran yang lebih efektif dan efisien. Beberapa fasilitas yang disediakan Moodle adalah modul bacaan, modul penugasan, modul chart, modul forum, modul pilihan, modul kuis dan sebagainya.

Pelaksanaan e-learning moodle pada sekolah memberikan dampak positif seperti kemandirian belajar peserta didik menjadi terasah, pembelajaran dapat dilakukan tanpa terikat ruang dan waktu. Namun juga terdapat kekurangan seperti keterbatasan jaringan. Beberapa kelebihan menggunakan e-learning Moodle yaitu antara guru dan peserta didik dapat berkomunikasi dengan mudah tanpa terikat 
ruang, jarak, dan waktu. Guru dan peserta didik dapat saling berkomunikasi atau berinteaktivitas dengan fitur video conference, diskusi, dan chatting. Namun dari beberapa kelebihan diatas juga terdapat kekurangan dalam pelaksanaan menggunakan e-learning Moodle diantaranya, belum tersedianya jaringan atau signal di seluruh daerah atau tempat, kurangnya keterampilan saat menggunakan e-learning Moodle, peserta didik yang tidak mempunyai motivasi belajar yang tinggi menggunakan elearning Moodle cenderung akan gagal.

SMA N 1 Temanggung merupakan salah satu sekolah yang memanfaatkan e-learning moodle. Terdapat beberapa fitur yang ada dalam e-learning Moodle diantaranya materi, assignment/quiz, forum diskusi, chat, dan video conference. Berdasarkan hasil wawancara dengan guru dan beberapa peserta didik, beberapa fitur dalam e-learning Moodle belum dilaksanakan secara optimal, yaitu fitur interaktivitas seperti fitur forum diskusi dan chatting dan fitur video conference, sehingga pelaksanaan fitur interaktivitas pada e-learning Moodle belum dilakukan sepenuhnya, kemudian rata-rata nilai hasil belajar peserta didik sebelum menggunakan Moodle yaitu 82 sehingga peneliti tertarik untuk mengetahui hasil belajar peserta didik setelah menggunakan e-learning Moodle apakah naik, stagnan atau menurun .

E-learning Moodle sendiri, sebelumnya sudah dilaksanakan namun penggunaanya masih minim, namun dengan adanya pandemi covid 19 ini e-learning Moodle dilaksanakan untuk pertama kali selama satu semester penuh atau dikatakan selama satu semester menggunakan pembelajaran daring sehingga belum diketahui secara pasti manfaat maupun dampak dari penggunaan e-learning Moodle selama satu semester di sekolah ini karena belum ada penelitian terkait. Peneliti tertarik melakukan penelitian di SMA N 1 Temanggung karena sekolah ini merupakan salah satu sekolah yang menerapkan pembelajaran di masa pandemi covid 19 pada satu platform yaitu Moodle yang terorganisir dengan jelas sehingga pembelajarannya terstruktur, berbeda dengan sekolah lain yang pembelajarannya menggunakan banyak platform secara terpisahpisah. Masalah yang terdapat dalam pembelajaran di masa pandemi covid ini tentu merupakan hal yang baru karena SMA N 1 Temanggung belum pernah melakukan pembelajaran jarak jauh secara penuh selama satu semester. Masalah-masalah lain dari hasil wawancara dan observasi yang ditemukan di sekolah ini yaitu, beberapa peserta didik ada yang lupa mengumpulkan tugas atau tidak mengumpulkan tugas tepat waktu di e-learning Moodle serta terdapat peserta didik yang terkendala sinyal saat mengerjakan tugas di $e$ learning Moodle.

Hasil observasi dan survey pada tanggal 3 November 2020, peneliti melakukan survey sederhana kepada peserta didik bahwa mata pelajaran matematika pada kelas 11 IPA merupakan mata pelajaran yang paling disukai. Hasil survey menunjukkan bahwa $19 \%$ peserta didik menyukai pelajaran matematika, $18 \%$ menyukai pelajaran fisika, $14 \%$ menyukai pelajaran pendidikan agama, $13 \%$ menyukai pelajaran penjasorkes, $9 \%$ menyukai pelajaran bahasa inggris, 7\% menyukai pelajaran biologi, serta sisannya menyukai pelajaran bahasa jawa, bahasa Indonesia, sastra inggris, kimia, pendidikan pancasila, sejarah, seni budaya dan prakarya. Dapat disimpulkan bahwa matematika merupakan mata pelajaran yang paling disukai oleh siswa kelas 11 IPA sehingga mata pelajaran yang disukai siswa dapat mendorong minat serta motivasi belajar siswa. Mata pelajaran matematika kelas 11 IPA dibagi menjadi 2, yaitu matematika wajib dan matematika peminatan. Perbedaan matematika wajib dan peminatan adalah untuk matematika wajib, semua jurusan di sekolah ini mengikuti (IPA maupun IPS) sedangkan matematika peminatan hanya jurusan IPA saja yang mempelajari dan materinya lebih dalam lagi tentang matematikanya. Berdasarkan permasalahan di atas, maka penelitian dengan judul "Pelaksanaan E-Learning Moodle di Masa Pandemi Covid 19 pada Mata Pelajaran Matematika Kelas 11 IPA SMA N 1 Temanggung" perlu dilakukan.

Tujuan penelitian ini adalah menganalisis pelaksanaan e-learning Moodle yang ditinjau dari perencaan, pelaksanaan, dan evaluasi, menganalisis manfaat dan dampak dalam pelaksanaan e-learning moodle dan menganalisis faktor yang mendukung, faktor yang menghambat dan solusi dalam pelaksanaan e-learning Moodle.

Penelitian ini diharapkan memiliki manfaat secara teoritis yang memiliki kontribusi untuk menambah wawasan dan pengetahuan yang berkaitan dengan pelaksanaan e-learning di suatu sekolah. Selain itu penelitian ini diharapkan juga memiliki manfaat praktis bagi guru untuk memberikan masukan dan informasi mengenai hambatan permasalah pelaksanaan $e$ - 
learning Moodle, bagi peserta didik untuk meningkatkan pengetahuan dan keterampilan dalam melaksanakan e-learning, bagi sekolah untuk memberikan informasi mengenai pelaksanaan e-learning dan masukan sebagai pertimbangan menentuka program selanjutnya, dan bagi Prodi Teknologi Pendidikan untuk memberi masukan mengenai e-learning Moodle dan pelaksanaannya.

\section{METODE PENELITIAN}

\section{Jenis Penelitian}

Penelitian ini menggunakan pendekatan kualitatif yang bersifat deskriptif. Penelitian ini termasuk penelitian yang menggunakan pendekatan kualitatif dan bersifat deskriptif karena penelitian ini bertujuan untuk mendeskripsikan dan menganalisis pelaksanaan e-learning Moodle di masa pandemi covid 19 pada mata pelajaran matematika kelas 11 IPA SMA N 1 Temanggung dari segi perencanaan, pelaksanaan serta evaluasi. Penelitian ini juga hendak mengungkapkan dampak dan manfaat, serta faktor pendukung, penghambat, dan solusi dalam pelaksanaan e-learning Moodle.

\section{Waktu dan Tempat Penelitian}

Pelaksnaan penelitian ini bertempat di SMA N 1 Temanggung yang beralamat di di Jl. Kartini No.4, Jampirejo Tengah, Jampirejo, Kec. Temanggung, Kabupaten Temanggung, Jawa Tengah. Sedangkan setting penelitian ini dilakukan di perpustakaan dan didalam kelas online yang terjalin antara guru dan peserta didik. Waktu penelitian ini dilakukan mulai bulan Maret sampai Mei 2021.

\section{Target/Subjek Penelitian}

Subjek dalam penelitian ini adalah guru matematika wajib dan matematika peminatan kelas 11 IPA yang berjumlah 4 orang dan peserta didik kelas 11 IPA yang berjumlah 6 orang yang diambil dengan menggunakan teknik purposive sampling berdasarkan kriteria peserta didik nilai tertinggi, nilai menengahm dan nilai terendah. . Subjek yang digunakan pada awal yaitu 6 orang siswa terlebih dahulu, namun ketika informasi yang didapat belum memuaskan maka subjek penelitiannya akan ditambahkan sampai datanya jenuh.

\section{Teknik Pengumpulan Data}

Teknik pengumpulan data yang digunakan adalah observasi untuk memperoleh fakta berdasarkan data, observasi yang digunakan adalah observasi tidak terstruktur dan observasi ditinjau dari keadaan sosial terkait pelaksanaan pembelajaran menggunakan $e$ learning moodle. Kemudian wawancara untuk mengetahui hal-hal yang lebih mendalam dari para narasumber baik guru maupun peserta didik untuk diketahui secara pasti informasi dari mereka dan dokumentasi untuk memperoleh data dan informasi dalam bentuk buku, arsip, dokumen, tulisan angka berupa laporan serta keterangan penelitian yang sangat berperan penting dalam penelitian ini.

\section{Teknik Analisis Data}

Teknik analisis yang peneliti gunakan dalam penelitian ini adalah teknik analisis data di lapangan model Miles dan Huberman (Sugiyono, 2014: 246) menyatakan bahwa usai kegiatan pengambilan data sudah terkumpul maka data terdapat tiga kegiatan utama dalam analisis yang saling berkaitan yaitu reduksi data, penyajian data, dan penarikan kesimpulan.

\section{HASIL PENELITIAN DAN PEMBAHASAN}

Data dalam penelitian ini bersumber dari kegiatan observasi partisipatif yang dilampirkan dalam hasil wawancara, data hasil observasi, dan hasil studi dokumentasi.

Perencanaan E-learning Moodle diperoleh berdasarkan observasi, wawancara, dan dokumentasi. Pembelajaran kelas 11 IPA sudah memiliki sarana dan prasarana yang memadai dilihat dari tersedianya laboratorium dengan wifi yang sudah sangat baik serta perpustakaan yang dapat digunakan baik secara online maupun offline namun pemanfaatannya berkurang karena peserta didik tidak ada yang ke sekolah dikarenakan pandemi covid 19 namun tetap dapat digunakan sebagai sumber belajar karena tersedia secara online perpustakaan yang dapat diakses melalui kubuku.id hal ini sesuai dengan pendapat Sumiati dan Asra (2009: 92) bahwa sumber belajar adalah sesuatu yang digunakan untuk tempat dimana materi materi pengajaran didapatkan. Kualitas sumber daya manusia yang sudah terdidik karena pelatihan sumber daya manusia yang mendukung dengan adanya 2 kali pelatihan guru secara offline 
dengan menerapkan protokol kesehatan dan sosialiasi video penggunaan moodle bagi peserta didik, selain itu guru sudah merancang RPP yang mencakup tujuan pembelajaran, indikator, metode pembelajaran, media pembelajaran, kegiatan pembelajaran, penilaian, serta lampiran materi, hal ini sesuai dengan Permendiknas Nomor 41 Tahun 2007, komponen RPP diantaranya diantaranya terdapat identitas mata pelajaran yang bersangkutan, standar kompetensi, kompetensi dasar, indikator pencapaian kompetensi, tujuan pembelajaran, materi ajar, alokasi waktu, metode pembelajaran, kegiatan pembelajaran, penilaian hasil belajar dan sumber belajar. Sehingga RPP yang digunakan pada pembelajaran matematika kelas 11 IPA sudah sesuai dengan peraturan Permendiknas dan sangat sesuai antara perencanaan di RPP dan pelaksanaanya di lapangan.. Perencanaan selanjutnya adalah kurikulum.Terdapat 5 Komponen dalam kurikulum, menurut Subandiyah (1993: 4) yaitu: (1) aspek tujuan pembelajaran, (2) aspek isi/materi, (3) aspek sarana dan prasarana, (4) aspek strategi pembelajaran dan (5) aspek proses belajar mengajar. Kurikulum yang digunakan adalah kurikulum darurat pandemi covid 19 yang diberikan oleh pemerintah, aspek dalam kurikulum darurat belum sesuai dengan komponen kurikulum pada umumnya, yang seharusnya pada kurikulum terdapat komponen media (sarana prasarana), komponen strategi dan komponen proses belajar mengajar yang belum ada. Selanjutnya adalah bahan ajar juga dipersiapkan untuk mendukung pelaksanaan $e$ learning Moodle seperti buku, video pembelajaran, maupun sumber-sumber dari google yang sudah sangat baik dan membantu pembelajaran hal ini sesuai dengan pendapat Djamarah dan Zain (2010: 43) mengatakan bahan pelajaran atau materi pelajaran adalah suatu pembahasan yang akan dijelaskan dan dinberikan pengarahan dalam proses belajar mengajar. Kemudian persiapan materi dengan merangkum materi kedalam bentuk powerpoint yang kemudian dibuat dalam bentuk video pembelajaran agar mudah dipahami. Hal ini sesuai dengan pendapat Djamarah dan Zain (2010: 43) menerangkan materi pembelajaran adalah substansi yang akan disampaikan dalam proses belajar mengajar.

Pelaksanaan e-learning moodle di masa pandemi covid 19 sudah sesuai dengan struktur program yang dirancang yang dimulai dengan mengingatkan peserta didik melalui platform whatsapp, guru mengupload materi, kemudian peserta didik dapat langsung mengisi presensi, guru membuka sesi tanya jawab dalam platform whatsapp mengenai materi yang belum di pahami, peserta didik dapat mengerjakan soal latihan yang telah diberikan guru setelah itu dikumpulkan, dan guru dapat melihat dan memberikan nilai terhadap proses belajar peserta didik yang dapat juga dengan memberikan feedback, hal ini sesuai dengan pendapat Majid (2005: 104) mengemukakan tahapan pembelajaran yaitu membuka atau menyambut pelajaran dengan baik dengan panduan, menyampaikan dan memproses transformasi informasi materi pelajaran, dan menutup pembelajaran dengan menimbulkan kesan pembelajaran yang dapat dipahami. Guru menggunakan model pembelajaran PBL atau problem based learning yang dimunculkan dalam materi berupa video pembelajaran dan soal latihan peserta didik. Metode yang digunakan adalah penugasan di e-learning moodle, tanya jawab pada platform whatsapp, dan ceramah pada video pembelajaran. Ceramah adalah suatu cara yang digunakan oleh guru untuk menyampaikan informasi kepada para pendengar di suatu ruangan (Suherman, 2001: 169). Menurut Alma (2010: 57) metode tugas dan resitasi dapat merangsang siswa untuk belajar lebih aktif baik secara individual maupun secara kelompok karena peserta didik dapat berlatih secara langsung dengan pemberian masalah. Kegiatan tersebut dapat terjadi pada fitur-fitur moodle yang sering digunakan seperti assignment, attendance, feedback, file, interactive content, quiz, dan URL. hal ini sesuai dengan pendapat Surjono (2013: 90) mengenai fasilitas yang terdapat dalam e-learning moodle. Tampilan moodle memberi kemudahan saat digunakan.

Evaluasi yang dilakukan pada pembelajaran kelas 11 IPA SMA $\mathrm{N} \quad 1$ Temanggung dilaksanakan menggunakan jenis evaluasi formatif dan sumatif. Evaluasi formatif dilakukan pada pertengahan semester berupa quiz atau ulangan, sedangkan evaluasi sumatif dilakukan pada akhir semester berupa ujian akhir semester. Evaluasi formatif dan evaluasi sumatif sangat membantu dalam melakukan penilaian kepada peserta didik untuk mengetahui perkembangan belajar mereka selama ini, apakah naik, stabil, atau menurun. Selain itu evaluasi pembelajaran juga dapat digunakan sebagai perbaikan guru dan juga peserta didik pada pembelajaran selanjutnya 
agar pembelajaran menjadi lebih terstruktur dan menambahi segala sesuatu yang masih menjadi kekurangan pada sebelumnya. Model evaluasi formatif dan evaluasi sumatif adalah model evaluasi yang seringkali ditemui karena selain pengaplikasian yang sederhana namun memiliki dampak yang baik terhadap hasil evaluasi dan juga mendalam karena diberikan periode waktu tertentu yaitu selama pertengahan semester dan juga akhir semester.

Hasil belajar peserta didik lebih meningkat menggunakan e-learning moodle di masa pandemi covid 19. Evaluasi adalah proses penting dalam pembelajaran untuk menentukan keberhasilan, tahapan ini penting karena untuk memperbaiki proses pembelajaran selanjutnya yang dapat dilihat dari pengamatan terhadap pelaksanaan pembelajaran yang telah dilaksanakan, hal ini sesuai dengan pendapat Mulyana (Rochayati dan Zakaria, 2010: 25). Hasil belajar peserta didik di masa pandemi covid 19 dengan menggunakan e-learning moodle lebih meningkat dibandingkan pembelajaran offline yang dilihat dari rekap nilai peserta didik, hal ini dapat dilihat dari hasil nilai rata-rata peserta didik yang tadinya 82 meningkat menjadi 85.

Manfaat e-learning Moodle diantaranya pembelajaran menjadi lebih terorganisir, pembelajaran dapat dilakukan dimana saja dan kapan saja, hasil belajar peserta didik meningkat menggunakan e-learning Moodle, hal ini sesuai dengan pendapat Sanaky (2013: 242) bahwa dengan adanya e-learning dapat belajar dimana saja dan kapan saja. Dampak e-learning Moodle diantaranya tidakadanya peningkatan motivasi belajar peserta didik. Hal ini sesuai dengan pendapat Rusman (2012: 323) yang dimana peserta didik yang tidak mempunyai motivasi cenderung akan gagal dan keterbatasan interaksi karena tidak terjalin komunikasi secara nyata, hal ini sesuai dengan pendapat Rusman (2012: 323) mengenai dampak penggunaan $e$-learning.

Faktor pendukung dalam pelaksanaan $e$ learning Moodle diantaranya kemandirian belajar peserta didik hal ini sesuai dengan prinsip e-learning menurut John dan Pegler (Wahyuningsih dan Makmur, 2017: 3), kemudian kesiapan belajar peserta didik, kesehatan jasmani, bantuan paket data, materi pembelajaran yang lengkap dan menarik, dukungan keluarga, dan sarana prasarana yang memadai. Sementara untuk faktor penghambat diantaranya kendala jaringan karena perbedaan wilayah dan server yang seringkali down. Solusi untuk mengatasi kendala tersebut adalah melakukan konsultasi kepada guru untuk menemukan dan mencari solusi, mengerjakan quiz susulan dengan soal yang berbeda, dan peserta didik dapat merefresh web berulang kali saat terjadi kendala server.

\section{SIMPULAN DAN SARAN Simpulan}

Berdasarkan hasil penelitian mengenai pelaksanaan E-Learning Moodle di masa Pandemi Covid 19 pada Mata Pelajaran Matematika kelas 11 IPA SMA N 1 Temanggung, maka peneliti dapat menarik kesimpulan sebagai berikut:

1. Perencanaan E-Learning Moodle di masa Pandemi Covid 19 pada Mata Pelajaran Matematika Kelas 11 IPA SMA N 1 Temanggung diantaranya persiapan sarana dan prasarana yang sudah memadai dengan adanya lab komputer dan perpustakaan yang dapat digunakan sebagai sumber belajar dan dukungan pemerintah dalam memberikan bantuan kuota, peserta didik dan guru sudah memiliki smartphone yang dapat digunakan untuk pembelajaran. Pengembangan sumber daya manusia dilakukan dengan 2 kali pelatihan guru dan video sosialiasi untuk peserta didik yang membantu dalam mengoperasikan moodle. Persiapkan RPP yang memenuhi standar meliputi indikator, media, kegiatan, penilaian dan kurikulum darurat covid 19 yang diberikan pemerintah berupa kompetensi dasar dan inti. Persiapan bahan ajar dengan menggunakan buku dan sumber dari google. Mempersiapkan materi pembelajaran yang bersumber dari bahan ajar dalam bentuk video pembelajaran. Perencanaan E-Lerning Moodle sudah sangat baik dan dilakukan secara detail.

2. Pelaksanaan E-Learning Moodle di masa Pandemi Covid 19 pada Mata Pelajaran Matematika kelas 11 IPA SMA N 1 Temanggung diakses melalui alamat web sman1temanggung.com. Pelaksanaan pembelajaran dilakukan sesuai jadwal pembelajaran. Guru mengingatkan peserta didik melalui whatsapp grup, guru mengupload materi video pembelajaran, guru membuka tanya jawab, guru memberikan feedback berupa nilai dan komentar yang dinilai dari pengetahuan dan keterampilan. Sementara peserta didik mengisi presensi, memahami materi, 
kemudian mengerjakan latihan soal yang berbentuk essay yang dikumpulkan dalam bentuk foto tugas yang telah dikerjakan. Tampilan moodle yang sederhana memberikan kemudahan digunakan, terdapat fitur yang beragam, fitur yang sering digunakan seperti assignment, attendance, feedback, file, interactive content, quiz, dan URL.

3. Evaluasi E-Learning Moodle di masa Pandemi Covid 19 pada Mata Pelajaran Matematika Kelas 11 IPA SMA N 1 Temanggung dengan menggunakan evaluasi formatif dan evaluasi sumatif. Evaluasi formatif dilakukan pada pertengahan semester dengan memberikan quiz atau ulangan harian. Sedangkan evaluasi sumatif dilakukan pada akhir semester dengan memberikan Ujian Akhir Semester atau UAS. Hasil belajar peserta didik meningkat dengan menggunakan $e$ learning moodle yang nilai rata-rata sebelum menggunakan adalah 82 setelah menggunakan naik menjadi 85 .

4. Manfaat E-Learning Moodle di masa Pandemi Covid 19 pada Mata Pelajaran Matematika Kelas 11 IPA SMA N 1 Temanggung diantaranya pembelajaran terorganisir, pembelajaran dapat dilakukan kapan saja dan dimana saja, dan hasil belajar peserta didik meningkat. Sementara dampaknya adalah tidak meningkatkan motivasi dan keterbatasan interaksi.

5. Faktor Pendukung dalam Pelaksanaan $E$ learning Moodle di masa Pandemi Covid 19 pada Mata Pelajaran Matematika Kelas 11 IPA SMA N 1 Temanggung diantaranya kemandirian belajar, kesiapan belajar, kesehatan jasmani, bantuan paket data, materi pembelajaran, dukungan keluarga, serta sarana dan prasarana. Faktor penghambat diantaranya keterbatasan jaringan dan server seringkali down. Solusi untuk mengatasinya adalah peserta didik yang terkendala saat mengerjakan quiz pada pertengahan dan akhir dapat mengikuti quiz susulan, kendala saat mengerjakan quiz pada awal dapat mengikuti quiz dengan soal yang sama namun namun waktu yang berbeda, dan peserta didik dapat merefresh berulang kali saat kendala server down terjadi
Saran

Setelah melakukan penelitian terkait dengan pelaksanaan e-learning moodle di masa pandemi covid 19 pada mata pelajaran matematika kelas 11 IPA SMA N 1 Temanggung, maka peneliti memberikan saran sebagai berikut:

1. Tahap Perencanaan E-Learning Moodle di masa Pandemi Covid 19 pada Mata Pelajaran Matematika Kelas 11 IPA SMA N 1 Temanggung

Perlu adanya pelatihan lanjutan mengenai semua fitur yang ada pada e-learning moodle karena pelatihan baru dilakukan pada beberapa fitur saja, sementara banyak fitur yang belum digunakan pada pembelajaran matematika kelas 11 IPA.

2. Tahap Pelaksanaan E-Learning Moodle di masa Pandemi Covid 19 pada Mata Pelajaran Matematika Kelas 11 IPA SMA N 1 Temanggung

Adakalanya pembelajaran dilakukan dengan menggunakan video conference untuk mengetahui pendidikan karakter peserta didik serta menjalin komunikasi berupa interaksi, dan video conference dapat digunakan saat quiz atau ulangan untuk mengetahui cara mengerjakan peserta didik sehingga sedikit kemungkinan peserta didik untuk bertanya kepada teman dan peserta didik yang sering terkendala jaringan saat mengerjakan quiz atau ulangan dapat memanfaatkan lab komputer yang ada di sekolah dengan alasan yang tepat agar tidak menerima quiz atau ulangan susulan dengan sol yang berbeda. Kegiatan ini dapat dilakukan sesuai dengan protokol kesehatan covid 19.

3. Tahap Evaluasi E-Learning Moodle di masa Pandemi Covid 19 pada Mata Pelajaran Matematika Kelas 11 IPA SMA N 1 Temanggung

Setelah masa pandemi covid 19 berakhir, diharapkan dengan adanya e-learning moodle tetap digunakan dengan menerapkan pembelajaran berbasis blended learning sebagai upaya mendukung era digital serta menambah kemudahan lebih dari sekedar elearning karena dengan metode campuran atau blended maka memudahkan peserta didik serta tetap ada kelas tatap muka dapat digunakan untuk melibatkan para peserta didik dalam pengalaman interaktif. 


\section{UCAPAN TERIMAKASIH}

Terimakasih kepada semua pihak yang telah mendukung penulisan jurnal ini, terimakasih kepada Allah SWT ,terimakasih kepada orang tua penulis, terimakasih kepada dosen pembimbing atau ketua penguji, terimakasih kepada penguji utama dan sekretaris penguji, terimakasih kepada teman-teman teknologi pendidikan angkatan 2017, terimakasih kepada jurusan Kurikulum dan Teknologi Pendidikan, dan Terimakasih Universitas Negeri Yogyakarta.

\section{DAFTAR PUSTAKA}

Darmawan, D. (2016). Pengembangan ELearning Teori dan Desain. Bandung: Remaja Rosdakarya.

Djamarah, S.B. \& Zain, A. (2010). Strategi Belajar Mengajar. Jakarta: Rineka Cipta.

Hamalik, O. (2002). Pendidikan Guru Berdasarkan Pendekatan Kompetensi. Jakarta: Bumi Aksara.

Majid, A. (2005). Perencanaan Pembelajaran: Mengembangkan Standar Kompetensi Guru. Bandung: PT Remaja Rosdakarya.

Permendiknas Nomor 41 Tahun 2007.

Prawiradilaga, D.S. (2016). Mozaik Teknologi Pendidikan: E-Learning. Jakarta: Prenadamedia Group.

Siahaan, M. (2020). Dampak Pandemi Covid-19 Terhadap Dunia Pendidikan. Jurnal Kajian Ilmiah (JKI), 1, 73-80.

Rochayati, U. \& Zakaria, M. (2010). Peningkatan Kualitas Pembelajaran Teknik Digital Melalui Pembelajaran Berbasis Lesson Study. JPTK, 19, 2144.

Sanaky, H. AH (2013). Media Pembelajaran Interaktif-Inovatif. Yogyakarta: Kaukaba Dipantara

Rusman. (2012). Belajar dan Pembelajaran Berbasis Komputer Mengembangkan Profesionalisme Abad 21. Jakarta: Alfabeta.
Subandiyah. (1993). Pengembangan dan Inovasi Kurikulum. Jakarta: Grafindo Persada.

Sugiyono. (2014). Metode Penelitian Pendidikan Pendekatan Kuantitatif, Kualitatif, dan $R \& D$. Bandung: Alfabeta.

Suherman, E. (2001). Strategi Pembelajaran Matematika. Kontemporer. Bandung: JICA-UPI.

Sumiati \& Asra. (2009). Metode Pembelajaran. Bandung: CV Wacana Prima.

Suranto, A.W. (2010). Komunikasi Sosial Budaya.Yogyakarta:Graha Ilmu.

Undang Undang Republik Indonesia Nomor 20 tahun (2003) Tentang Sistem Pendidikan Nasional.

Yuliana. (2020). Corona Virus Diseases (Covid 19); Sebuah Tinjauan Literatur. Wellness And Healthy Magazine, 2, 187-192.

Yuliastuti, N., Pujayanto, \& E. Y. Ekawati. (2014). Pengembangan Media Pembelajaran IPA Terpadu Berbasis Elearning Dengan Moodle Untuk Siswa Sekolah Menengah Pertama Pada Tema Pengelolaan Sampah. Jurnal Pendidikan Fisika, 2(1): 15-20.

Tigowati. (2017). The Influence of the Use of Elearning to Student Cognitive Performance and Motivation in Digital Simulation Course. Indonesian Journal of Informatics Education, 1, 41-48.

Alma, B. (2010). Guru Profesional: Menguasai Metode dan Terampil Mengajar. Bandung: Alfabeta.

Wahyuningsih, D \& Makmur, R. (2017). Elearning Teori dan Aplikasi. Bandung: Informatika Bandung. 